\section{Anisakidae in fishing products sold in Sicily}

\author{
Vincenzo Ferrantelli, Antonello Cicero, \\ Antonella Costa, Angelina Alongi, \\ Paola Palumbo, Stefania Graci, \\ Giuseppe Giangrosso \\ Centro di Referenza Nazionale per le \\ Anisakiasi (C.Re.N.A.), Istituto \\ Zooprofilattico Sperimentale della Sicilia, \\ Palermo, Italy
}

\section{Abstract}

One of the parasite diseases associated with the consumption of raw fish that occurs with some frequency is the anisakiasis, a human disease caused by the accidental ingestion of larval nematodes of the genus Anisakis, family Anisakidae. At the National Reference Centre for Anisakiasis (C.Re.N.A.) from October 2012 to February 2013, a number of 231 bony fish (Trichiuridae, Engraulidae, Scombridae and Clupeidae) were received from different fishing sites in Sicily. Anisakis pegreffii is the main species detected in fish, as identified by molecular analysis based on polymerase chain reaction-restriction fragment length polymorphism, while Anisakis simplex sensu stricto was found only in Scomber scombrus caught in the Mediterranean Sea (Fishing Areas 37), in the Spanish coast (Fishing Areas 37) and in the Atlantic Ocean (Fishing Areas 34). Larvae of the genus Pseudoterranova were found only in fish caught in the Norwegian Sea.

\section{Introduction}

In the last ten years, in our country, there has been an increase in the consumption of raw fish due to the introduction of new eating habits from countries outside Europe (sushi, sashimi, herring, pickled anchovies, etc.), increasing the risk of contracting parasitic diseases, in particular the anisakiasis (Audicana et al., 2002). Anisakiasis is a disease caused by nematodes of the genus Anisakis, belonging to the Anisakidae family, with Pseudoterranova, Contracaecum and Hysterothylacium genus. Human infestation occurs by ingestion of thirdstage Anisakis larvae present in raw fish and cephalopods but also undercooked, marinated, pickled, smoked or salted.

These parasites are found, at the adult stage, in the abdomen of marine mammals (whales, seals, dolphins), more precisely in the stomach where they are visible to the naked eye. In fish, which are intermediate hosts, the larval form are normally found in the coelomic cavity where they can found free or encysted or adherent to the various organs and tissues (Mattiucci and Nascetti, 2008). In the past you may encounter traumatic injuries, and fibrinous adhesions due to the presence of the parasite that passes from the gastrointestinal tract to the coelomic cavity to reach the flesh. In humans the anisakiasis may manifest as an acute form with a predominantly gastric localisation, characterised by nausea, vomiting and epigastric pain that occur after 4-6 h after ingestion of fish parasitised. We distinguish localised forms where you can discover granulomas in the submucosa, with the presence of eosinophils (eosinophilic granulomas) and diffuse forms characterised by an edematous infiltration that affects the entire gastric or intestinal wall called eosinophilic Phlegmon (Mattiucci et al., 2011).

It is also an intestinal form that develops after about 7 days post infection with abdominal pain, nausea, vomiting, fever, diarrhea and fecal occult blood. The parasites, however, introduced into the body, induce an increase in immunoglobulins of class E (IgE) with IgEmediated reactions such as urticaria, angioedema, anaphylaxis, asthma (Urban et al., 1992). The finding of a positive specific IgE in a certain percentage of asymptomatic subjects and in patients with urticaria, angioedema or anaphylaxis triggered by foods not parasitised, has led to speculation that there may be an initial sensitisation to Anisakis, asymptomatic, with the appearance of new symptoms after exposure to allergens (Mattiucci et al., 2013; Audicana and Kennedy, 2008; Daschner et al., 2012). Because of all these implications on human health, the Italian legislation has put in place, in 1992 an initial regulatory approach of the Health Ministry Circular No. 10 of 11/03/1992 and subsequent Ordinance $12 / 05 / 1992$, which recommended to the fishermen and operators involved in the handling of fresh fish to provide for a timely gutting for fish with size exceeding $18 \mathrm{~cm}$ belonging to the species Lepidopus caudatus, Engraulis encrasicholus, Scomber scombrus, Merluccius merlucius, Sardina pilchardus, Bramidae brama. Fish or parts thereof that clearly have parasites should not be placed on the market. More recently, the European Community, with the enactment of the so-called Hygiene Package and in particular with Regulation (UE) No. 1276/2011 defines the following: Food business operators placing on the market the following fishery products derived from finfish or cephalopod molluscs: (a) fishery products intended to be consumed raw; or (b) marinated, salted and any other treated fishery products, if the treatment is insufficient to kill the viable parasite. Must ensure that the raw material or finished product undergo a freezing treatment in order to kill viable parasites that
Correspondence: Vincenzo Ferrantelli, Centro di Referenza Nazionale per le Anisakiasi (C.Re.N.A.), Istituto Zooprofilattico Sperimentale della Sicilia, via Gino Marinuzzi 3, 90129 Palermo, Italy.

Tel. +39.091 .6565455 - Fax: +39.091 .6565234 .

E-mail: vincenzo.ferrantelli@izssicilia.it

Key words: Anisakis, Pseudoterranova, Sicily.

Contributions: all the authors contributed equally.

Conflict of interests: the authors declare no potential conflict of interests.

Funding: the work was financially supported by the Italian Ministry of Health.

Conference presentation: part of this paper was presented at the 23rd National AIVI Congress, 2013 June 12-14, Rome, Italy.

Received for publication: 14 May 2013

Revision received: 9 September 2013.

Accepted for publication: 11 September 2013.

This work is licensed under a Creative Commons Attribution 3.0 License (by-nc 3.0).

(C) Copyright V. Ferrantelli et al., 2014

Licensee PAGEPress, Italy

Italian Journal of Food Safety 2014; 3:1719

doi:10.4081/ijfs.2014.1719

may be a risk to the health of the consumer. For parasites other than trematodes the freezing treatment must consist of lowering the temperature in all parts of the product to at least: (a) $-20^{\circ} \mathrm{C}$ for not less than $24 \mathrm{~h}$; or (b) $-35^{\circ} \mathrm{C}$ for not less than $15 \mathrm{~h}$ (European Commission, 2011).

In addition, with the spread of fashion consumption of raw fish, the Ministry of Health with prot. n. 4379 of 17/02/2011 specifies that, as foreseen in the Regulation (EC) n. 1020/2008, also in retail must be complied with the specific requirements of parasites and those relating to the visual examination for their research in accordance with the provisions in Regulation (EC) No 853/2004. According to the above note, the food business operator if it were to carry out operations of filleting and/or slicing should submit the same to visual inspection as required by Regulation (EC) No 2074/2005. If the OSA would produce raw or almost raw fishery products using chilled, he must demonstrate that the treatments used, whatever they are, ensure the killing of all parasites that may be present in the product ready for consumption. To give support to the emerging problems regarding the presence of Anisakis in fish products and to carry out the monitoring of the Italian seas has been activated the National Reference Centre for Anisakiasis (C.Re.NA) at headquarters of Institute Zooprophilactic Sperimental of Sicily (IZSSI). In the present study larval forms of 
Anisakidae collected in fishing products sampled in Sicily were identified by molecular analysis.

\section{Materials and Methods}

This study was conducted on the samples received at the Center from October 2012 to February 2013. In this period were analysed 231 fish (Lepidopus caudatus, Engraulis encrasicolus, Merluccius merluccius, Sardina pilchardus, Scomber scombrus, Longing longing, Trachurus trachurus, Mullus surmuletus), sampled caught in Sicilian seas (Fishing Areas 37), parasitised by a total of 1299 larvae of the Family Anisakidae. 157 of them (67.96\%) were parasitised by larvae of the Anisakidae family while $74(32.03 \%)$ were not parasitised. The larvae, taken from viscera (n. 1296), organs and muscles (n. 3) of fish were counted with the help of the stereo microscope and identified at genus level by light microscopy. The Anisakis spp. larvae recovered and identified were then preserved in $70 \%$ ethanol until molecular analysis based on polymerase chain reaction-restriction fragment length polymorphism (PCR-RFLP). In this molecular technique, after the DNA extraction, the DNA regions of ITS1, ITS2 and 5.8 SrRNA was amplified by PCR using the primer pair NC5/NC2 (Zhu et al., 1998) and the amplified was subjected to enzymatic restriction using the enzymes Hinf I and Hha previously shown to be diagnostic for the species of Anisakis.

Different species of Anisakis give rise to restriction fragments that allow the species identification (Anisakis pegreffii, Anisakis physeteris, Anisakis typica, Anisakis simplex C, Anisakis ziphidarum and Anisakis simplex sensu stricto) (D'Amelio et al., 2000). The DNA was also purified and subjected to sequencing to confirm the identification through homology with the sequences found in GeneBank. Several larvae were collected from fish caught in the Norwegian Sea and morphologically identified at genus level by light microscopy as Pseudoterranova.

\section{Results and Discussion}

Of the 231 fish received, 1299 larvae were collected and were identificated by microscop- ic observation and molecular investigations. The majority of the larvae belonged to the genus Anisakis and to the species Anisakis pegreffii. The species Anisakis simplex was found only in Scomber scombrus caught in the Mediterranean Sea near the Spanish coasts and in the Atlantic Ocean (Fishing Areas 34 and 37) according to Cavallero et al. (2012) and Bernardi et al. (2011). Waiting to confirm this data, the species Anisakis pegreffii seems to be mainly found in Sicilian Seas in relation to the presence of cetaceans such as definitive hosts (Mattiucci and Nascetti, 2008).

\section{Conclusions}

It is known that larvae of different species of Anisakis are widespread in several fish species of economic and commercial concern in Italian seas an that the consumption of raw fish, expecially marinated anchoves, is locally common. A. pegreffii is the most common species detected in fish from the Mediterranean Sea and is a zoonotic agent of a human anisakiasis in Italy. Larvae belonging to the genus Pseudoterranova were found in samples of wetsalted Cod wings of Gadus morhua caught in the Norwegian Sea (Faroe Islands) (Nadolna and Podolska, 2013).

\section{References}

Audicana MT, Ansotegui JJ, de Corres LF, Kennedy MW, 2002. Anisakis simplex: dangerous -dead and alive? Trends Parasitol 18:20-5.

Audicana MT, Kennedy MV, 2008. Anisakis simplex: from obscure infectious worm to inducer of immune hypersensitivity. Clin Microbiol Rev 21:360-9.

Bernardi C, Gustinelli A, Fioravanti ML, Caffara M, Mattiucci S, Cattaneo P, 2011. Prevalence and mean intensity of Anisakis simplex (sensu stricto) in European sea bass (Dicentrarchus labrax) from Northeast Atlantic Ocean. Int $\mathrm{J}$ Food Microbiol 148:55-9.

Cavallero S, Ligas A, Bruschi F, D’Amelio S, 2012. Molecular identification of Anisakis spp. from fishes collected in the Tyrrhenian Sea (NW Mediterranean). Vet
Parasitol 187:563-6.

D’Amelio S, Mathiopoulos KD, Santos CP, Pugachev ON, Webbd SC, Picanco M, Paggi L, 2000. Genetic markers in ribosomal DNA for the identification of members of the genus Anisakis (Nematoda: Ascaridoidea) defined by polymerase chain reaction-based restriction fragment length polymorphism. Int $\mathrm{J}$ Parasitol 30:223-6.

Daschner A, Cuéllar C, Rodero M, 2012. The Anisakis allergy debate: does an evolutionary approach help? Trends Parasitol 28:915.

European Commission, 2011. Commission regulation of 8 December 2011 amending Annex III to Regulation (EC) No 853/2004 of the European Parliament and of the Council, 1276/2011/EU. In: Official Journal, L 327/39, 9/12/2011.

Mattiucci S, Fazii P, De Rosa A, Paoletti M, Salomone Megna A, Glielmo A, De Angelis M, Costa A, Meucci C, Calvaruso V, Sorrentini I, Palma G, Bruschi F, Nascetti G, 2013. Anisakiasis and gastroallergic reactions associated with Anisakis pegreffii infection, Italy. Emerg Infect Dis 19:4969.

Mattiucci S, Nascetti G, 2008. Advances and trends in the molecular systematics of anisakid nematodes, with implications for their evolutionary ecology and host-parasite co-evolutionary processes. Adv Parasit 66:147-8.

Mattiucci S, Paoletti M, Borrini F, Palumbo M, Macarone Palmieri R, Gomes V, Casati A, Nascetti G, 2011. First molecular identification of the zoonotic parasite Anisakis pegreffii (Nematoda: Anisakidae) in a paraffin-embedded granuloma taken from a case of human intestinal anisakiasis in Italy. BMC Infect Dis 11:82.

Nadolna K, Podolska M, 2013. Anisakid larvae in the liver of cod (Gadus morhua) L. from the southern Baltic Sea. J Helminthol 4:110.

Urban FJ, Madden KB, Svetic A, Cheever A, Trotta PP, Gause WC, Katona IM, Finkelman FD, 1992. The importance of Th2 cytokines in protective immunity to nematodes. Immunology Rev 127:205-20.

Zhu X, Gasser RB, Podolska M, Chilton NB, 1998. Characterisation of anisakid nematodes with zoonotic potential by nuclear ribosomal DNA sequences. Int J Parasitol 28:1911-21. 